\title{
Hydrology of a segment of a glacier situated in an overdeepening, Storglaciären, Sweden
}

\author{
ROGER LEB. HOOKE \\ Department of Geology and Geophysics, University of Minnesota, Minneapolis, Minnesota 55455, U.S.A. \\ Veijo A. Pohjola \\ Department of Physical Geography, University of Uppsala, Uppsala, Sweden
}

\begin{abstract}
Tracer experiments, and water-level observations made while drilling 47 boreholes in an overdeepened section of Storglaciären, have demonstrated that nearly all of the water passing through this part of the glacier moves in englacial conduits. Much of the viscous energy dissipated by subglacial water flowing up an adverse bed slope out of such an overdeepening may be needed to warm the water to keep it at the pressure-melting point. If the adverse slope is sufficiently steep, freezing may occur within the conduits. The possibility for enlargement of conduits by melting is thus limited and water pressures become high. We infer that this, combined with possible blocking of conduits by freezing, forces the water to seek englacial pathways.

The frequency with which englacial conduits are encountered during drilling suggests that there are several hundred of them in any given cross-section of the glacier. Consequently, each must carry a small fraction of the total discharge, say $\sim 10^{-3} \mathrm{~m}^{3} \mathrm{~s}^{-1}$. Tracer experiments suggest that flow rates in these conduits are $<10^{-1} \mathrm{~m} \mathrm{~s}^{-1}$, so conduit cross-sectional areas must be $\sim 10^{-2} \mathrm{~m}^{2}$, a size that is consistent with video observations in boreholes. The observed mean hydraulic gradient through the overdeepening is $\sim 0.04$. If the conduits were of uniform crosssectional area, the roughness implied by these figures would be unreasonably high and water pressures in them would be lower than observed. Thus, we hypothesize that conduits are locally constricted to only a small fraction of their average crosssectional area.
\end{abstract}

\section{INTRODUGTION}

Storglaciären is a small valley glacier in northern Sweden (Fig. 1) that has a photographic record extending back to about 1880. Modern scientific studies on it began as early as 1946 when Schytt (1959, 1981; Holmlund, 1987) initiated the still-continuing mass-balance measurements. Recent papers have discussed its bed topography (Björnsson, 1981) and composition (Brand and others, 1987), mass balance (Holmlund, 1987, 1988), surface deformation and flow (Hooke and others, 1983b, 1989; Jansson and Hooke, 1989), temperature regime (Hooke and others, 1983a; Holmlund and Eriksson, 1989), internal deformation (Hooke and others, 1987) and hydrology (Hooke and others, 1988; Seaberg and others, 1988; Hock and Hooke, 1993). This paper represents a continuation of the latter studies.

Although predominantly temperate, Storglaciären has a perennially cold $\left(<0^{\circ} \mathrm{C}\right)$ surface layer, $20-60 \mathrm{~m}$ thick, in its ablation area (Holmlund and Eriksson, 1989). Hydrologically, this layer is impermeable. Thus, water penetrates to the englacial part of the glacier-drainage system principally by way of crevasses and moulins that extend through the layer.
Near the middle of its ablation area, Storglaciären flows over a riegel, or transverse bedrock ridge (Fig. 1). For $\sim 1 \mathrm{~km}$ up-glacier from this riegel, the bed is overdeepened. Crevasses open over the riegel and also over the headwall at the up-glacier end of this overdeepening (Fig. 1). These are the primary input points for water in this part of the glacier. There are also some lateral crevasses along the sides of the overdeepening and some water enters the drainage system through these. Discussed here are tracer experiments designed to study the water flow beneath and through this overdeepening.

Storglaciären is drained by two primary streams, Nordjåkk and Sydjåkk (Fig. 1). Sydjåkk normally carries a significant sediment load, while Nordjåkk is much cleaner. Previous tracer studies (Hooke and others, 1988; Seaberg and others, 1988; Kohler, 1992; Hock and Hooke, 1993) have demonstrated that water entering the glacier by way of the crevasses and moulins over the riegel appears in Sydjåkk, whereas water entering higher on the glacier exits in Nordjåkk. The difference in sediment concentration is taken to indicate that water in Sydjåkk travels some distance along the bed, whereas that in Nordjåkk follows predominantly englacial pathways. 


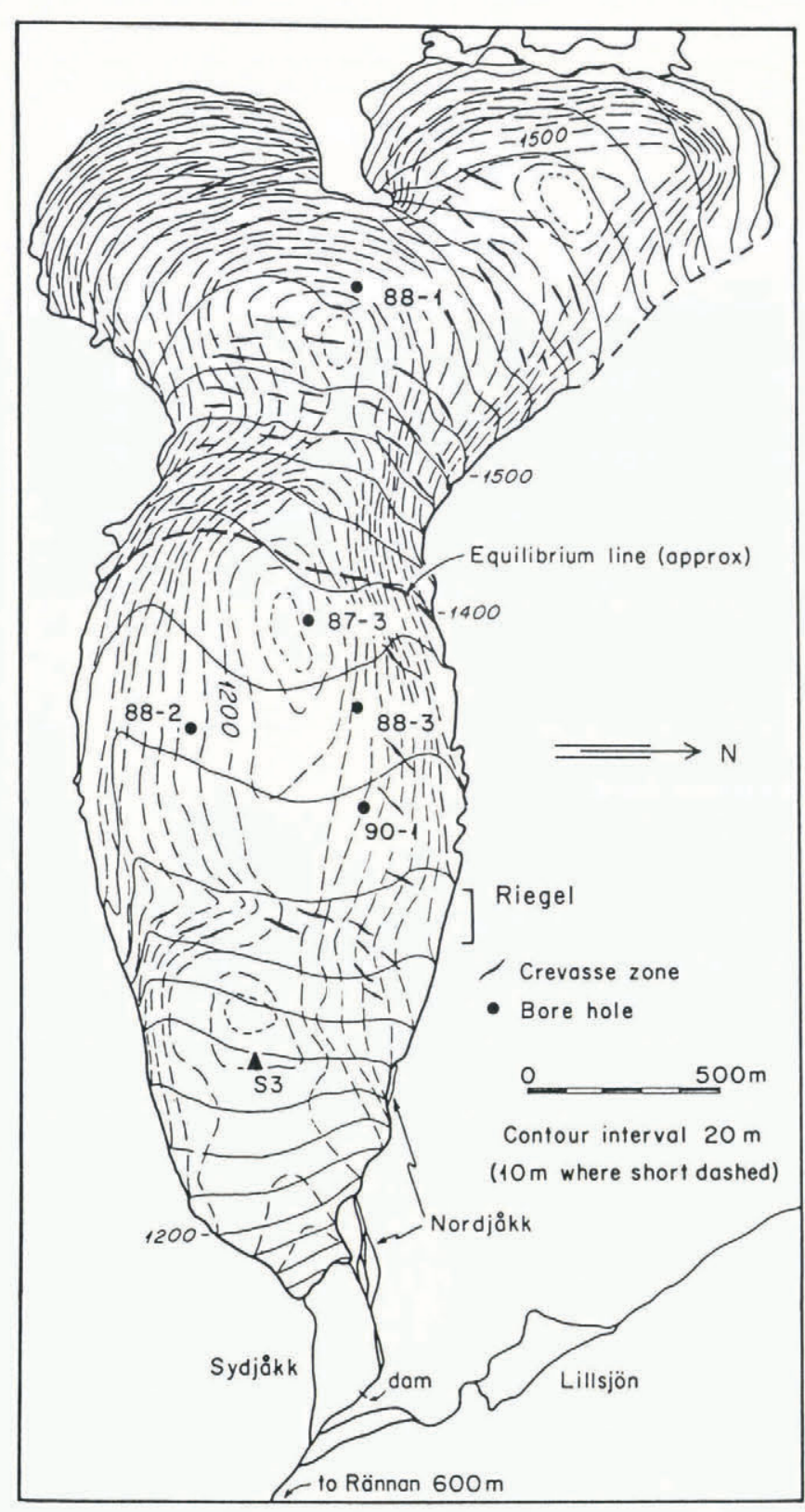

Fig. 1. Map of Storglaciären showing surface and bed topography, locations of crevasse zones through which water enters the englacial drainage system and locations of boreholes used as injection points for tracer experiments and of other holes mentioned in the text.

Nordjåkk, or at least a major branch thereof, first appears on the north side of the glacier, below the riegel, at about the $1280 \mathrm{~m}$ level (Fig. 1). It crosses morainal material here, before plunging once again beneath the ice. To the extent that any of this water is near or at the bed where it crosses the riegel, this suggests that it may already be well up on the (subglacial) valley side. Such a situation has been described by Hantz and Lliboutry (1983) at glacier d'Argentière, where, since 1979, water has crossed a riegel beneath that glacier at a point $\sim 340 \mathrm{~m}$ from and at least $25 \mathrm{~m}$ above the lowest point of the riegel.

Electrical resistivity experiments (Brand and others, 1987), seismic studies (unpublished data of J. Paetz) and direct sampling through boreholes (unpublished data of N. R. Iverson) suggest that throughout the overdeepening the glacier is underlain by a discontinuous layer of till, $0.2-0.5 \mathrm{~m}$ thick. Normally, it might be expected that such till would be flushed from the glacier sole through subglacial conduits. However, when water flowing up an adverse slope out of an overdeepening does not dissipate enough viscous energy to keep it warmed to the pressure-melting point, there may not be enough energy available to maintain such conduits. Classical theory (Röthlisberger, 1972) then requires that conduits be held open by high water pressures instead but, once the overburden pressure is reached, water would spread out under the glacier rather than be confined in conduits. Hooke (1991) attributed the till layer in the overdeepening to this lack of conduits and hence of flushing.

\section{PROCEDURES}

Forty-seven bore-holes were drilled in the overdeepening between 1982 and 1990, using a hot-water drill. The holes were entirely in ice as no firn was present, this part of the glacier being in the ablation area, and any residual snow cover was removed prior to drilling. Thus, while drilling was in progress, water overflowed from the holes as long as no connection to an active drainage conduit was established. Upon making such a connection, the water level dropped from the surface and the hole was said to have drained. This is not to imply that water levels fell to great depths. In fact, subsequent measurements revealed that the water level was normally no more than $20-40 \mathrm{~m}$ below the surface. Hantz and Lliboutry (1983) reported identical experiences during drilling in the overdeepening on glacier d'Argentière.

Tracer experiments, using either crystalline salt or a saline water solution, were used to determine the depth at which water left some of these holes. The tracer was poured into a hole, into which a small surface stream was flowing. A pair of electrodes connected to a battery and an ammeter were then used to monitor the movement of the salt cloud in the hole.

Additional tracer experiments, using rhodamine WT, were designed to study flow from some holes to the glacier terminus. The injection sites were boreholes 87-3, 88-1, 88-2 and 88-3 (Fig. 1; Table 1). The first of these was drilled in 1987 and the other three in 1988. The primary sampling site was the hydrological station, Rännan (Fig. 1), during test $88: 1$ and Nordjåkk dam during the other tests. Some samples were collected in Sydjåkk to confirm that no dye was passing through that part of the system. Samples were collected by hand and with the use of an Esco automatic water sampler, and were analyzed in the laboratory at Tarfala Research Station using procedures described previously (Seaberg and others, 1988, p. 218).

The minimum flow velocity through the glacier (Table 1) was obtained by dividing the straight-line distance between the injection point and the glacier terminus by the elapsed time between injection and the first peak of the dye-return curve. The elapsed time was adjusted for the time required for water to traverse the distance between the glacier terminus and the sampling point, using a velocity-discharge relation for proglacial Sydjåkk established by Seaberg and others (1988, fig. 5). Dispersion coefficients were obtained from the dye-return 
Table 1. Summary of tracer experiments

\begin{tabular}{|c|c|c|c|c|c|c|c|c|c|}
\hline \multirow[t]{2}{*}{ Year } & \multirow[t]{2}{*}{ Test } & \multirow[t]{2}{*}{ Date } & Time & \multirow[t]{2}{*}{ Borehole } & \multirow{2}{*}{$\begin{array}{c}\text { Discharge } \\
\mathrm{m}^{3} \mathrm{~s}^{-1}\end{array}$} & \multirow{2}{*}{$\begin{array}{l}\text { Velocity } \\
\mathrm{ms}^{-1}\end{array}$} & \multirow{2}{*}{$\begin{array}{l}\text { Dispersion } \\
\text { coefficient }\end{array}$} & \multirow{2}{*}{$\begin{array}{c}\text { Dispersivity } \\
\text { m }\end{array}$} & \multirow{2}{*}{$\begin{array}{c}\text { Recovery } \\
\%\end{array}$} \\
\hline & & & $\mathrm{h}$ & & & & & & \\
\hline \multicolumn{10}{|l|}{1987} \\
\hline & $87: 1$ & $14 \mathrm{Jul}$ & 1500 & $87-3$ & 0.38 & 0.019 & 1.9 & 100 & 60 \\
\hline & $87: 2$ & $27 \mathrm{Jul}$ & 0920 & $87-3$ & 0.27 & 0.011 & 2.1 & 191 & 45 \\
\hline & $87: 3$ & 3 Aug & 0950 & $87-3$ & 1.58 & 0.089 & 6.7 & 75 & 82 \\
\hline \multicolumn{10}{|l|}{1988} \\
\hline & $88: 1$ & $4 \mathrm{Jul}$ & 1300 & $88-1$ & & 0.025 & 14.6 & 584 & 75 \\
\hline & $88: 2^{*}$ & $11 \mathrm{Jul}$ & 1820 & $88-2$ & & & & & \\
\hline & $88: 3^{*}$ & $16 \mathrm{Jul}$ & 1300 & $88-3$ & & & & & \\
\hline
\end{tabular}

* These tests are referred to as $88: 2,3$ in the text for reasons explained there.

curves using the procedure described by Seaberg and others $(1988$, p. 222). The dispersivity, which is a measure of the intensity of braiding of the conduit system (Seaberg and others, 1988, p.225), is obtained by dividing the dispersion coefficient by the velocity (Table 1 ).

In some of the holes we installed pressure transducers, fabricated from automobile oil-pressure gauges and monitored them with data loggers. In a few instances, when transducers were not available, water levels were measured manually at frequencies ranging from several times per day to once every several days.

In 1989, we inspected four holes in this part of the glacier with the use of a video camera. The lens on this camera could be rotated through $220^{\circ}$ about a vertical axis and through approximately $85^{\circ}$ about a horizontal axis, thus permitting detailed study of the hole sides. In 1990 , these observations were continued using a less sophisticated video system. In these later experiments, no attempt was made to inspect hole sides, but data were obtained on the bed and on the (relative) concentration of suspended material in the water.

\section{RESULTS}

\section{Borehole studies}

Of the 47 holes discussed here, $66 \%$ connected with active englacial drainage conduits, $13 \%$ drained at the bed and $21 \%$ did not drain. Holes that drained at the bed usually drained slowly; sometimes the fact that drainage was occurring was not detected until the following day. Hole 88-2, $132 \mathrm{~m}$ deep and near the south side of the glacier (Fig. 1), was one of those that drained at the bed and, when water was not actively flowing into it, the water level in it often dropped to or nearly to the bed.

In holes that drained, with the exception of hole 88-2, the water level was normally no more than $20-40 \mathrm{~m}$ below the surface (Fig. 2) and variations in level were relatively small (Fig. 3). Early in the season, the water pressure at the bed was commonly close to the iceoverburden pressure, as is evident from the proximity of the points in Figure 2 to the water-equivalent line. There was a tendency for levels to fall as the melt season progressed (Fig. 3), presumably reflecting enlargement of drainage conduits by energy dissipated by the flowing water.

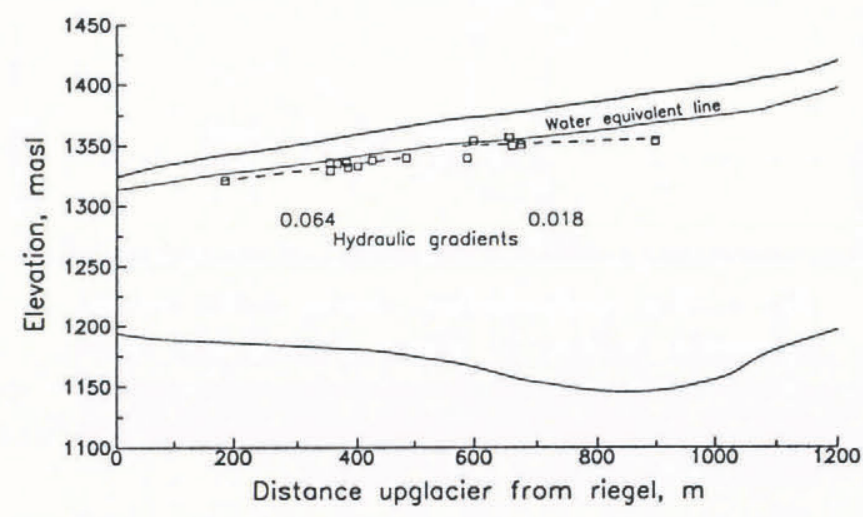

Fig. 2. Longitudinal section of Storglaciären through the overdespening, showing bed and surface topography and water-equivalent line. Also shown are water levels in boreholes projected on to the plane of the section. These water levels are approximate averages over the period during which the hole was under observation; in some instances, this "period" included only one measurement made shortly after the hole was completed. In a few holes, the pressure appears to have exceeded the overburden pressure; whether these represent local areas of overpressure at the bed or errors in measurement of either the water level or the ice thickness is not known. Ice thicknesses were normally obtained from measurements of the length of hose required to reach the bed so, if holes were not plumb, as sometimes was evident, the thickness may have been overestimated. When a hole was known to be off vertical, radio-echo data were used to determine the thickness (Eriksson, unpublished map). 


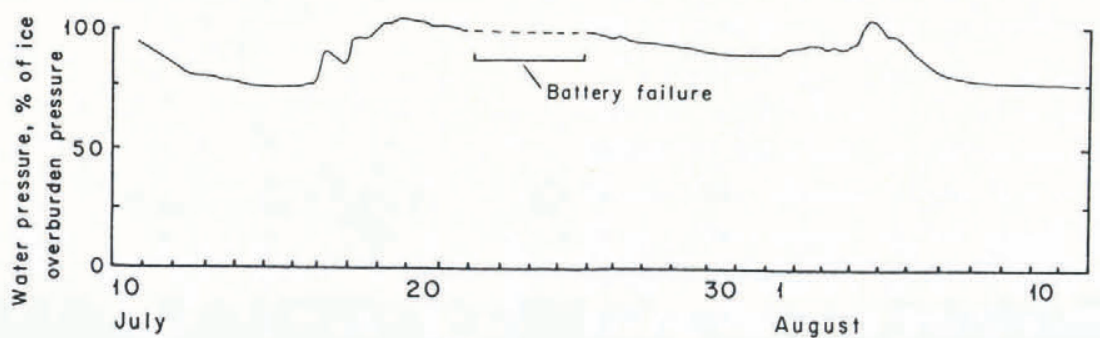

Fig. 3. Variation in water level through time in borehole 90-1.

These experiences are remarkably similar to those of Hantz and Lliboutry (1983) in borehole experiments in the overdeepening of glacier d'Argentière. As on Storglaciären, they found that many holes drained englacially; that holes draining at the bed often drained slowly; that, except for holes near the valley sides, water pressures were commonly high, approaching overburden pressure; that holes near the valley sides were typically empty of water, suggesting the presence of a nearby conduit at approximately atmospheric pressure; that water-pressure fluctuations occurred over periods of days or weeks, but not diurnally; that water pressures tended to decline through the melt season; and that nearby holes behaved differently in some instances. These similarities suggest that our joint findings are typical of water behavior in glacier overdeepenings.

The salt-trace experiments established that active conduits had been intersected at the "drainage depth" or level where the drill tip stood when a hole drained. In experiments with crystalline salt, the salt was flushed from the upper part of the hole within a few hours, but remained concentrated below the drainage depth for over a day (Hooke and others, 1988, fig. 2). Below the drainage depth, the salt concentration decreased with depth, suggesting that water might be upwelling from the bed to drain through the englacial conduit. In the experiments using dissolved salt, the salt cloud could be followed down the hole until it disappeared at the drainage depth.

The video experiments in 1990 support these conclusions. After being allowed to stand for several days, water in the tops of the holes was clear enough for use of the camera. At greater depths, however, the water was invariably cloudy. The transition between the clear and cloudy water was normally abrupt. When the drainage depth was known, it coincided with the top of this sediment plume. We again infer that upper parts of these holes were flushed by clear water entering from the surface and that, near the bottom, fine sediment was held in suspension by upwelling of water from the bed. Observations during the more-detailed 1989 video surveys differed somewhat, in that in three of four holes the top of the sediment plume was from 3 to $70 \mathrm{~m}$ below the drainage depth and was quite diffuse.

The video surveys from 1989 revealed, on average, three or four openings in hole sides that could have served as englacial conduits. However, nylon string suspended in front of the camera usually hung motionless; either the string was too stiff to detect the low water velocities in these passages or there was, at the time of the surveys, little flow in the majority of them. Some of these openings contained a few sand or gravel particles that might once have been in transit. The passages ranged from $\sim 0.1$ to $\sim 0.4 \mathrm{~m}$ in height. In cross-sectional shape, many were either irregular or oval, while some appeared to be subhorizontal cracks that extended beyond the hole sides (Pohjola, in press).

Active englacial drainage conduits were not encountered at depths less than $50 \mathrm{~m}$ (Fig. 4). This presumably reflects the existence of the surface layer of cold ice, which is typically $20-50 \mathrm{~m}$ thick in this part of the glacier (Holmlund and Eriksson, 1989). The deepest that such conduits occurred was within a meter or two of the bed. There was no apparent systematic variation in the depth to active conduits. In fact, in two instances in which holes were drilled within $1 \mathrm{~m}$ of each other (for electrical resistivity measurements), englacial conduits were encountered 2 and $4 \mathrm{~m}$ apart vertically, respectively (Brand and others, 1987).

(Experiences during the 1992 field season reinforced some of the above observations and gave a new perspective on others. Fourteen holes were drilled to the bed in a smaller overdeepening (site S3, Fig. 1). Penetrometer tests indicated that 13 of the holes bottomed in till. Water levels were initially well above the water-equivalent level in 12 holes, and from 20 to 22 July, water containing frazil ice and fine sediment overflowed from three of them. Presumably, the water was coming from the bed. Then on 23 July, following a storm, water levels dropped to depths of at least several

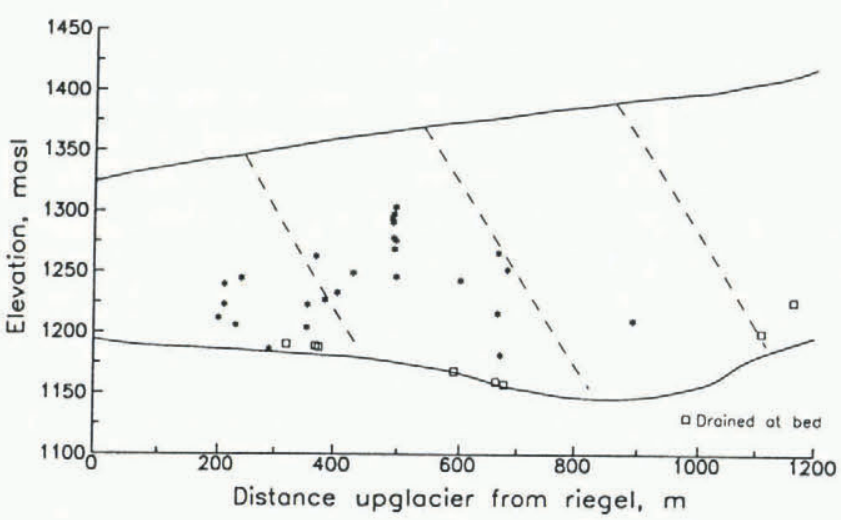

Fig. 4. Longitudinal section of Storglaciären through the overdeepening, showing depths at which holes drained. Because depths were projected laterally on to the line of profile, square symbols, indicating holes that drained at the bed, may appear to lie somewhat above or below the bed in the figure. Dashed lines are traces of equipotential surfaces (see text). 
tens of meters. We infer that the initial overpressures led to formation of connections between areas of thicker ice up-glacier and the borehole site, and hence in the overflow and that these connections were later extended to the down-glacier end of this overdeepening, resulting in the subsequent drop in water levels. In summary, as in the larger overdeepening further up-glacier, water pressures were high and subglacial till was present but, in contrast to the situation in the larger overdeepening, no englacial passages were encountered.)

\section{Dye-trace experiments}

Dye-return curves for the 1987 tests show well-defined single peaks (Fig. 5). However, the dispersivities derived from these tests (Table 1) are much higher than those of $\sim 2 \mathrm{~m}$ to, at most, $\sim 50 \mathrm{~m}$ obtained at about the same time of year from tracer tests from moulins over the riegel

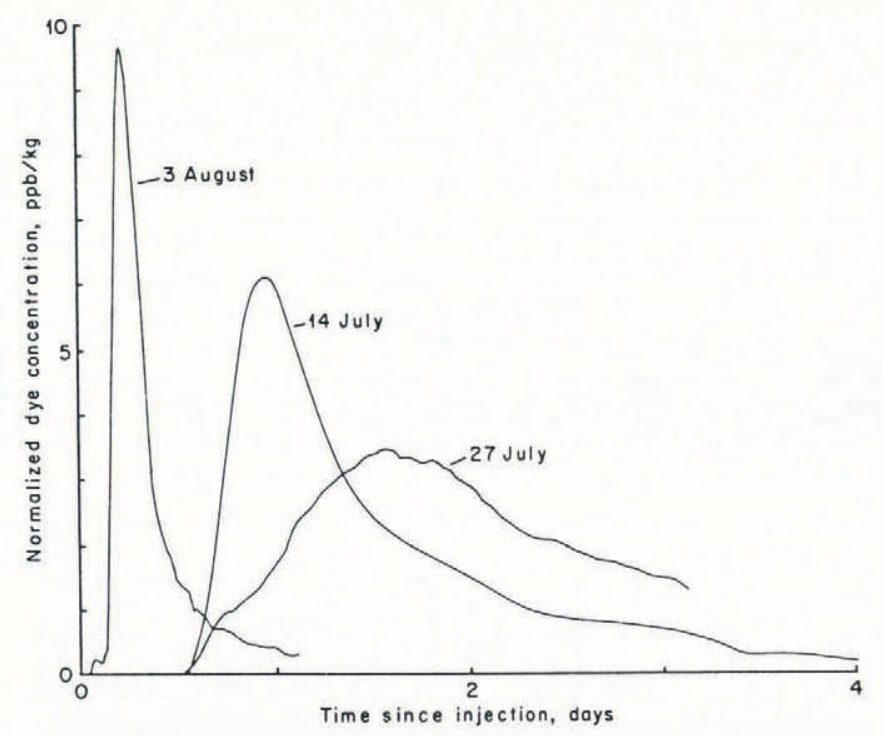

Fig. 5. Dye-return curves for tracer experiments 87:1, 87:2 and $87: 3$. The curves have been normalized to $1 \mathrm{~kg}$ of dye input to permit direct comparison of dye concentrations between tests.

(Seaberg and others, 1988; Hock and Hooke, 1993). Note also that dispersivity increases between the first and second tests. This is contrary to the normal pattern, in which dispersivity decreases as the conduit system becomes better integrated (Seaberg and others, 1988; Hock and Hooke, 1993).

The dye-return curve for test $88: 1$ (Fig. 6) has two peaks. Apparently much of the dye was retarded by about $1 \frac{1}{4} \mathrm{~d}$, either in a storage from which dye is released only during the peak daily discharges, or in a separate conduit through which dye moved more slowly.

The dye-return curve for tests $88: 2,3$ (Fig. 7) differs dramatically from those for the previous tests. The principal differences are attributed (below) to the fact that the boreholes in which these injections were made, 88-2 and 88-3, both drained at the bed rather than through englacial conduits. In addition, note that the declining dye concentrations during the first 4-7d of this experiment may be the tail of the return curve from

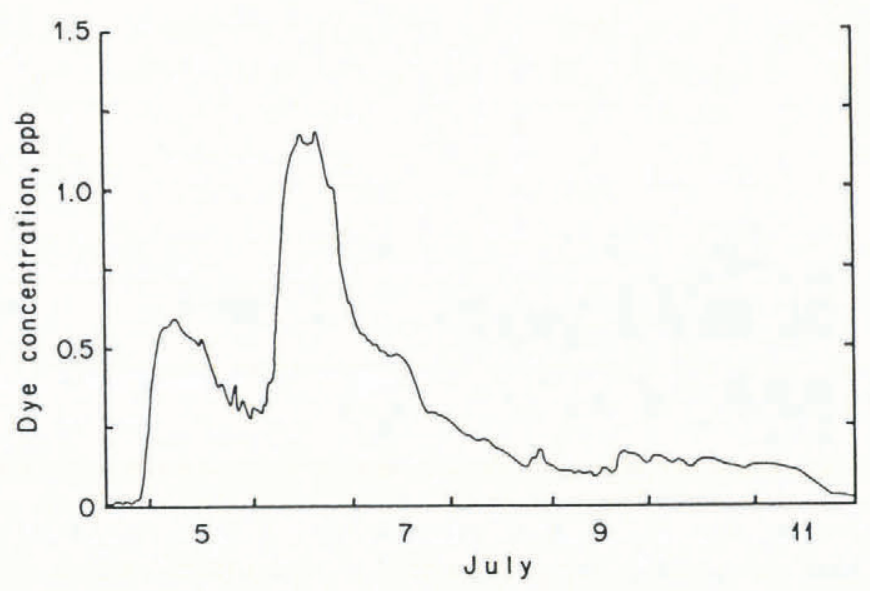

Fig. 6. Dye-return curve for tracer experiment 88:1.

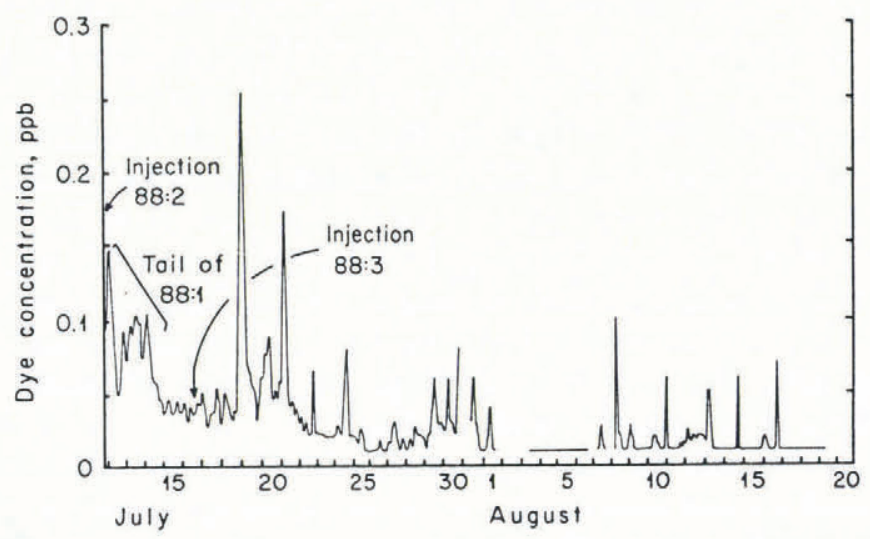

Fig. 7. Dye-return curve for tracer experiment $88: 2,3$.

experiment 88:1. This would further imply that perhaps no dye was recovered from injection $88: 2$ in hole $88-2$. If any dye was recovered from this test, it is indistinguishable from that from injection 88:3. Thus, henceforth, these tests are referred to as test $88: 2,3$.

\section{DISGUSSION}

\section{Flow at the bed}

The dye-return curve from tracer test $88: 2,3$ suggests that flow along the bed is sporadic. Dye appears to be trapped in pockets for extended periods of time. Releases sometimes, but not always, appear to be triggered by high water inputs. These results are consistent with those of an earlier tracer test in a stream flowing into a crevasse about $400 \mathrm{~m}$ northwest of hole 87-3 (Hooke and others, 1988). We suppose that the storage pockets are between the glacier sole and the subglacial till layer that we believe is present throughout most of the overdeepening. The multiplicity of dye releases over many days suggests that these pockets are multiply interconnected so that the dye is split into numerous separated packets that have widely differing residence times beneath the glacier. During the 1989 video surveys, we observed a part of this release process in action. While the camera was focused on the bed, a sediment cloud entered the borehole along the icebed interface and progressed across the field of view, obscuring the bed (Pohjola, 1993). 


\section{Discharge in englacial conduits}

There appear to be a large number of englacial conduits, each carrying a small fraction of the total discharge. For example, if holes were to be drilled in a straight line across the central $600 \mathrm{~m}$ of the glacier, roughly the region over which our drilling program extended, the 1989 video surveys suggest that we would intersect an average of four englacial passages per hole. Based on the frequency with which holes drained during drilling, one of these passages would be expected to be active in two-thirds of the holes. Given that the conduits were observed to be a few decimeters across, we could argue that holes drilled on $0.5 \mathrm{~m}$ centers would intersect different conduits. Thus, in the $600 \mathrm{~m}$ transect, we would have 1200 independent boreholes intersecting 4800 conduits of which $\sim 800$ (onequarter of two-thirds) would be active. Our dye-trace experiments indicate that water draining through these conduits appears in Nordjåkk which has a mean discharge of $\sim 1.1 \mathrm{~m}^{3} \mathrm{~s}^{-1}$ (Hock and Hooke, 1993). Dividing this evenly among the 800 conduits gives a mean discharge per conduit of $\sim 0.0014 \mathrm{~m}^{3} \mathrm{~s}^{-1}$. These figures will be used in some of the calculations that follow.

\section{Theoretical considerations}

The reason for the high pressures in the overdeepening is readily understood; as an adverse bed slope becomes increasingly steep, more of the viscous energy is needed to warm the water as the pressure-melting point beneath the down-glacier thinning ice increases. Thus, less energy is available to enlarge conduits by melting and the tendency for conduit closure must be balanced by high water pressures rather than by melting.

Where the adverse bed slope exceeds $\sim 1.3-2.0$ times the surface slope, the viscous energy available may not be sufficient to keep water warmed to the pressure-melting point. (The lower figure is appropriate for air-saturated water and the higher one for pure water (Röthlisberger and Lang, 1987, p. 245)). In conduits exceeding this critical slope, supercooling would occur. Conduits might then freeze up or, perhaps more likely, ice crystals may nucleate on impurities in the water, forming frazil ice (verbal communication from D. E. Lawson, July 1992). Such frazil ice could form aggregates that would clog smaller conduits (Strasser and others, 1992).

Shreve (1972) showed that equipotential surfaces in a glacier should dip up-glacier with a slope of $\sim 11$ times the slope of the glacier surface. Three such equipotential surfaces are shown in Figure 4. Englacial water flow is expected to be normal to these surfaces. Upon reaching the bed, water should flow along the ice-bed interface in a direction normal to contours of equipotential defined by the intersection of these surfaces with the bed. Shreve (1985) successfully explained a number of characteristics of eskers using this model. Shreve's model assumed that the difference between the pressure in the conduits and that in the surrounding ice is small and that there are no significant spatial variations in this difference.

When the slope of a bed leading out of an overdeepening exceeds the critical value noted above, there is an obvious inconsistency: Shreve's model requires the water to descend to the bed and then flow along it, while
Röthlisberger's, which is supported by our field observations, suggests that conduits would then become blocked.

\section{Water pressures in englacial and subglacial conduits}

We next investigate water pressures in an englacial conduit that is parallel to, but some distance above the bed, vis-á-vis one lying along the bed. The conduits are assumed to be hydraulically connected. Thus, water would tend to flow from the conduit at the higher potential towards that at the lower potential. Röthlisberger (1972), Lliboutry (1983, p. 224) and Röthlisberger and Lang (1987, p. 261) have all approached this problem by assuming that discharges in the two conduits were different and asking which would carry the larger discharge. Lliboutry concluded that the higher conduit would carry most of the flow, but Röthlisberger and Lang argued that Lliboutry had misinterpreted his equations and that they actually demonstrated the opposite result.

Here, we approach the problem slightly differently; instead of asking which conduit will carry more water, we assume that both carry the same discharge and ask which will have the higher hydraulic grade line. The result is not obvious from the governing differential equation (Röthlisberger, 1972, equation (20)) so we integrated it numerically for the specific geometry of Storglaciären, and show the resulting energy grade lines in Figure 8. In performing this integration, we assumed that subglacial conduits are broad and low, or lenticular, as Hooke and others (1990) argued should be the case. Water pressures in such conduits are much higher than those in classical circular or semi-circular Röthlisberger conduits because plastic flow of the ice closes lenticular conduits more rapidly. We also assumed that the drainage system downglacier from the riegel consists of an arborescent network of conduits in which, for modeling purposes, the discharge is halved five times between the terminus and the riegel. Velocities in such an arborescent conduit system match observed velocities much better than is the case for a system consisting of a single conduit (Hock and Hooke, 1993). Above the riegel, the discharge per conduit is taken to be $0.0014 \mathrm{~m}^{3} \mathrm{~s}^{-1}$, as discussed above. We assume a Manning roughness of $0.05 \mathrm{~m}^{-\frac{1}{\mathrm{~s}} \mathrm{~s}} \mathrm{~s}$, which would seem to be reasonable for conduits entirely in ice, though possibly slightly low for those at the bed.

When both the englacial and subglacial conduits are assumed to be lenticular, the conduit above the bed has an energy grade line that is slightly higher throughout most of the overdeepening (Fig. 8). This would imply a tendency for water to move from the higher conduit to the one at the bed whenever the opportunity presented itself. However, if we assume that the englacial conduit is circular in shape, it will close much more slowly, thus requiring a lower water pressure and hence lower hydraulic grade line (Fig. 8). Using a higher roughness for the conduit at the bed, say $0.2 \mathrm{~m}^{-\frac{1}{3}} \mathrm{~s}$, also increases the pressure here above that in an englacial lenticular conduit. In either case, water would tend to move from the lower to the higher conduit. As noted, this is what is inferred to be happening in the boreholes when they provide a pathway between the bed and an englacial 


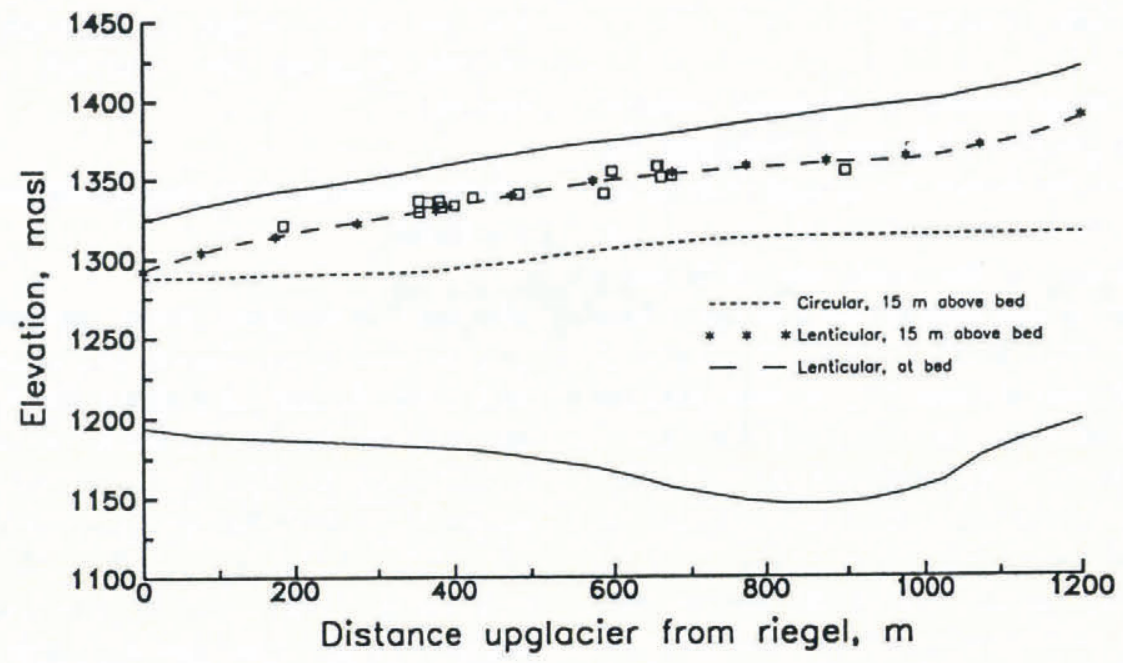

Fig. 8. Energy grade lines through overdeepening calculated for different drainage configurations. As discussed in the text, an arborescent network of broad, low conduits is assumed to exist down-glacier from the riegel. Up-glacier from the riegel, conduits that are "above bed" are assumed to be horizontal until they reach an elevation of $15 \mathrm{~m}$ above the bed. Thereafter, they parallel the bed. Water levels in boreholes (Fig. 2) are shown by square symbols.

conduit. Some of the water ascending in this way might be expected to freeze, much as it would while flowing up an adverse bed slope. However, water ascending from the bed may have a solute content sufficient to inhibit such freezing.

A conduit receiving water from another will be enlarged at the expense of the other (Shreve, 1972). Then, because the steady-state water pressure in a conduit decreases as discharge increases, the conduit at the lower potential would continue to increase in size in a positive feed-back (Röthlisberger, 1972).

As a result of these temporal and spatial variations in conduit roughnesses, in conduit sizes and shapes, and in locations of blockages, we infer that the potential field near the bed is distorted in such a way as to induce flow of water from subglacial to englacial conduits. Thus, we conclude that Shreve's (1972) model for the potential field breaks down near a bed with a sufficiently steep adverse slope.

Water pressures calculated using the model with lenticular conduits are remarkably consistent with those measured (Fig. 8). The measured hydraulic gradient, which is relatively flat in the middle of the overdeepening and steeper toward the riegel, is also well reproduced. This agreement suggests that the circular approximation for the cross-sectional shape of englacial conduits may not be a good one. However, of the conduits observed in the 1989 video experiment, $70 \%$ were oval or sub-circular, while the rest were lenticular (Pohjola, in press).

\section{Flow speeds in the conduits}

The average hydraulic gradient through the overdeepening is $\sim 0.041 \mathrm{~m} \mathrm{~m}^{-1}$ (Fig. 2). Using, again, a roughness of $0.05 \mathrm{~m}^{-\frac{1}{3}} \mathrm{~s}$, we find that circular conduits with a diameter of $\sim 0.08 \mathrm{~m}$ would be required to transport a discharge of $0.0014 \mathrm{~m}^{3} \mathrm{~s}^{-1}$, and the flow speed in the conduit would be $\sim 0.3 \mathrm{~m} \mathrm{~s}^{-1}$. For the particular geometry assumed for the lenticular conduits (Hooke and others, 1990, table 1), the cross-sectional area of the conduit is somewhat larger but its height is $<0.01 \mathrm{~m}$. The velocity in this case is $\sim 0.2 \mathrm{~m} \mathrm{~s}^{-1}$. These conduit sizes are smaller to much smaller than those observed in the 1989 video experiments, while the velocities are 2 to nearly 30 times those recorded in the 1987 dye-trace experiments (Table 1). Because the flow is actually in much larger conduits over much of the distance between borehole 87-3 and the terminus, the actual discrepancy in the velocities is even worse.

To match the highest velocities from the 1987 tracer experiments would require a circular conduit with a diameter of $0.14 \mathrm{~m}$ and roughness of $0.25 \mathrm{~m}^{-\frac{1}{3}} \mathrm{~s}$. The former is consistent with observation but the latter borders on the unreasonable. To match the lower velocities would require still larger conduits with grossly unreasonable roughnesses.

One resolution of this apparent inconsistency is to assume that passageways are constricted locally. In the case of the $\sim 75 \%$ of the conduits that are inactive, we hypothesize that these constrictions have closed the passages completely. Suppose we assume that constrictions in active circular conduits are $50 \mathrm{~mm}$ long and $20 \mathrm{~mm}$ in diameter and that they, too, have a roughness of $0.05 \mathrm{~m}^{-\frac{1}{3}} \mathrm{~s}$. Suppose further that, between constrictions, the conduit has a diameter $D$ of $0.2 \mathrm{~m}$. Then, if the conduit is carrying a discharge $Q$ of $0.0014 \mathrm{~m}^{3} \mathrm{~s}^{-1}$, one constriction every $70 \mathrm{~m}$ would suffice to increase the head loss to that observed. Because the constrictions are such a small fraction of the total conduit length, the average velocity will be essentially $Q / \pi(D / 2)^{2}$ or, in this case, $0.045 \mathrm{~m} \mathrm{~s}^{-1}$. This is near the middle of the observed range (Table 1).

However, as noted, velocities in conduits in the overdeepening must be less than the mean, as those in the trunk conduits further down-glacier are much higher. To match these lower velocities would require larger conduits or lower discharges per conduit, or both, along with appropriate changes in the distance between constrictions. As mean conduit size is constrained by the video observations and is unlikely to be much larger than 
$0.2 \mathrm{~m}$, the actual number of active conduits through any given cross-section of the overdeepening may be underestimated.

This model of the conduit system provides a possible explanation for the unexpected increase in dispersivity between tests $87: 1$ and $87: 2$, and the subsequent decrease to test 87:3 (Fig. 5; Table 1). Some conduits may have become constricted between the first two injections, and either the same conduits or others may have opened between the second and third tests. This suggests a rather more dynamic englacial drainage system than previously suspected.

Such constrictions would raise pressures in the conduits. In the case of the circular conduits, this could explain why observed pressures are higher than those calculated (Fig. 8). These elevated pressures serve to offset the higher closure rates that would otherwise occur in larger conduits.

The origin of these constrictions, if they actually exist, is unclear. Ice flow over the riegel or freezing of ascending supercooled water might be factors. Once formed, however, we presume that they can persist, in part because energy dissipated by water flowing through them is carried downstream and consumed by melting of ice in larger parts of the passages rather than in the constrictions themselves.

\section{CONCLUSIONS}

The number of tracer experiments and video surveys we have run is not large and some surprises may be in store, but so far the pattern is consistent and seems to be well explained by our conceptual model. Water flow along the bed in overdeepenings appears to be through multipleinterconnected pockets in which dye can be stored for protracted periods of time. In contrast, water following englacial passageways moves more directly, albeit still slowly, to the terminus. The frequency with which such englacial conduits are encountered implies that there are a great number of them, at least in the larger of the overdeepenings (Fig. 1). The low velocities in these conduits, indicated by tracer studies, are consistent with the sizes observed in the video surveys. For such low velocities to occur in such large conduits, however, the flow must be throttled. Such throttling would explain the high water pressures, which are necessary to offset closure in larger conduits. The high dispersivities in these conduits could be a consequence of the constrictions or could mean that the conduits are interconnected, forming a braided system. The increase in dispersivity between tests $87: 1$ and $87: 2$ may indicate that conduits are easily disrupted.

Theoretical considerations suggest that conduits at the glacier sole in areas of sufficiently steep adverse bed slope are easily blocked by freezing and that water may thus be forced to follow pathways leading upward into the glacier, diverging significantly from the mean direction of the maximum potential gradient as envisioned by Shreve (1972). If englacial conduits are at slightly lower pressures, however, the potential field may be distorted, favoring transfer of water from basal to englacial locations. Such distortion is inferred to be a consequence of differences in potential in neighboring conduits, resulting from temporal and spatial variations in roughness, size and shape of conduits, and from scattered plugging of conduits by freezing. This results in a highly dynamic, unstable system with new conduits opening in response to high pressures thus generated.

As noted, our basic observations jibe well with those of Hantz and Lliboutry (1983). However, our interpretations differ from theirs in important respects. First and most crucially, they did not recognize that elevated water pressures may be a natural consequence of flow up an adverse slope (Röthlisberger, 1972). Coupled with their tacit assumption that the glacier was underlain by hard rock rather than till, this led to uncertainty about the interpretation of the high water pressures. Secondly, they underestimated the significance of the englacial passages encountered during drilling and, in particular, the contribution of these passages to the permeability of the ice. Thus, whereas they emphasized transverse gradients in piezometric pressure and the possibility that water is driven laterally through a slightly permeable ice by these gradients, we suspect that longitudinal flow in englacial conduits with scattered constrictions is more important. That flow is predominantly longitudinal is implied by the fact that the principal source for water flowing in these conduits is melt in the accumulation area. This water enters the glacier by way of the crevasses just above the equilibrium line (Fig. 1).

\section{ACKNOWLEDGEMENTS}

We are grateful to the many people involved with the program at Tarfala Research Station who, over the years, have assisted in the collection of the data upon which this paper is based, and who contributed to the pleasant atmosphere at the station. Particular recognition is accorded D. Wiberg, who conducted the tracer experiments. M. Funk's critical comments resulted in significant improvements in the paper.

This research was funded by the U.S. National Science Foundation (grants DPP 86-19086 and 8822156, and INT 87-12749) and the Swedish Natural Sciences Research Council.

\section{REFERENCES}

Björnsson, H. 1981. Radio-echo sounding maps of Storglaciären, Isfallsglaciären and Rabots glaciär, northern Sweden. Geogr. Ann., 63(3-4), 225-231.

Brand, G., V. Pohjola and R. LeB. Hooke. 1987. Evidence for a till layer beneath Storglaciären, Sweden, based on electrical resistivity measurements. F. Glaciol., 33(115), 311-314.

Hantz, D. and L. Lliboutry. 1983. Waterways, ice permeability at depth, and water pressures at glacier d'Argentière, French Alps. J. Glaciol., 29(102), 227-239.

Hock, R. and R. LeB. Hooke. 1993. Evolution of the internal drainage system in the lower part of the ablation area of Storglaciären, Sweden. Geol. Soc. Am. Bull., 105(4), 537-546.

Holmlund, P. 1987. Mass balance of Storglaciären during the 20th century. Geogr. Ann., 69A(3-4), $439-447$.

Holmlund, P. 1988. Is the longitudinal profile of Storglaciären, northern Sweden, in balance with the present climate? $\mathcal{f}$. Glaciol., 34(118), 269-273. 
Holmlund, P. and M. Eriksson. 1989. The cold surface layer on Storglaciären. Geogr. Ann., 71A(3-4), 241-244.

Hooke, R. LeB. 1991. Positive feedbacks associated with erosion of glacial cirques and overdeepenings. Geol. Soc. Am. Bull., 103(8), 1104-1108.

Hooke, R. LeB., J.E. Gould and J. Brzozowski. 1983a. Near-surface temperatures near and below the equilibrium line on polar and subpolar glaciers. Z. Gletscherkd. Glazialgeol., 19(1), 1-25.

Hooke, R. LeB., J. Brzozowski and C. Bronge. 1983b. Seasonal variations in surface velocity, Storglaciären, Sweden. Geogr. Ann., 65A(3-4), 263-277.

Hooke, R. LeB., P. Holmlund and N. R. Iverson. 1987. Extrusion flow demonstrated by bore-hole deformation measurements over a riegel, Storglaciären, Sweden. 7. Glaciol., 33(113), 72-78.

Hooke, R. LeB., S. B. Miller and J. Kohler. 1988. Character of the englacial and subglacial drainage system in the upper part of the ablation area of Storglaciären, Sweden. F. Glaciol., 34(117), 228-231.

Hooke, R. LeB., P. Calla, P. Holmlund, M. Nilsson and A. Stroeven. 1989. A 3 year record of seasonal variations in surface velocity, Storglaciären, Sweden. 7. Glaciol., 35(120), 235-247.

Hooke, R. LeB., T. Lauman and J. Kohler. 1990. Subglacial water pressures and the shape of subglacial conduits. F. Glaciol., 36(122), 67-71.

Jansson, P. and R. LeB. Hooke. 1989. Short-term variations in strain and surface tilt on Storglaciären, Kebnekaise, northern Sweden. F. Glaciol., 35(120), 201-208.

Kohler, J. 1992. Glacial hydrology of Storglaciären, northern Sweden. (Ph.D. thesis, University of Minnesota, Minneapolis.)

Lliboutry, L. 1983. Modifications to the theory of intraglacial waterways for the case of subglacial ones. F. Glaciol., 29(102), 216-226.
Pohjola, V.A. 1993. TV-video observations of bed and basal sliding on Storglaciären, Sweden. F. Glaciol., 39(131), 111-118.

Pohjola, V.A. In press. TV-video observations of englacial voids in Storglaciären, Sweden. F. Glaciol.

Röthlisberger, H. 1972. Water pressure in intra- and subglacial channels. f. Glaciol., 11(62), 177-203.

Röthlisberger, H. and H. Lang. 1987. Glacial hydrology. In Gurnell, A.M. and M.J. Clark, eds. Glacio-fluvial sediment transfer; an alpine perspective. New York, etc., John Wiley and Sons, 207-284.

Schytt, V. 1959. The glaciers of the Kebnekajse massif. Geogr. Ann., 41(4), 213-227.

Schytt, V. 1981. The net mass balance of Storglaciären, Kebnekaise, Sweden, related to the height of the equilibrium line and to the height of the $500 \mathrm{mb}$ surface. Geogr. Ann., 63A(3-4), 219-223.

Seaberg, S. Z., J. Z. Seaberg, R. LeB Hooke and D. W. Wiberg. 1988. Character of the englacial and subglacial drainage system in the lower part of the ablation area of Storglaciären, Sweden, as revealed by dye-trace studies. F. Glaciol., 34(117), 217-227.

Shreve, R. L. 1972. Movement of water in glaciers. F. Glaciol., 11(62), 205-214.

Shreve, R.L. 1985. Esker characteristics in terms of glacier physics, Katahdin esker system, Maine. Geol. Soc. Am. Bull., 96(5), 639-646.

Strasser, J. C., D. E. Lawson, E. B. Evenson, J. C. Gosse and R. B. Alley. 1992. Frazil ice growth at the terminus of the Matanuska Glacier, Alaska, and its implications for sediment entrainment in glaciers and ice sheets. Geol. Soc. Am. Abstracts with Programs, 24(3), 78.

The accuracy of references in the text and in this list is the responsibility of the authors, to whom queries should be addressed.

MS received 19 March 1992 and in revised form 24 November 1992 